M.D. (1932). The impact of his book Detachment of the Retina, published by the Cambridge University Press in 1931, was inevitably lessened by the fact that Gonin's revolutionary work on this subject had begun to attract world-wide attention while Anderson's work was being written. Nevertheless Anderson's book contained many sound observations, and the work that it involved gave him an abiding concern with the problem of retinal detachment. His work on Hydrophthalmia was another important contribution to our specialty.

Early in the 1930s Anderson became interested in disorders of ocular muscle balance. He felt that some of the pioneer claims concerning orthoptic treatment were too optimistic, but he firmly believed that, with proper selection of patients, orthoptic treatment offered a great opportunity to improve binocular function. He was also convinced that, whatever differences of opinion there might be with regard to the efficacy of treatment, there could be no reasonable doubt that orthoptic investigation by properly trained auxiliaries was an immense help in everyday practice. When the Second World War came, Anderson's special knowledge of ocular muscle imbalance was an immeasurable asset for the Royal Australasian Air Force to which he was appointed as consultant ophthalmic surgeon, as well as to the Australian Navy.

Anderson was a wide traveller and an assiduous attender at Congresses, not only in Australia where he was often an office-holder and a principal contributor to the programme, but also throughout the world. As a visitor to clinics in Great Britain, Europe and America, he was a delightful guest; and as a thoughtful and considerate host in Australia he was supreme. His speech as Australian representative at the inaugural ceremony of the XVI International Congress in London, 1950, was remarkable for its virile sincerity. Even more memorable was his masterly survey of ocular muscle imbalance delivered in New York 4 years later at the XVII International Congress of Ophthalmology. The ground covered in this talk, together with much other first-class work, can be found in the second edition of his Ocular Vertical Deviations and the Treatment of Nystagmus, published by the British Medical Association in 1959.

In the middle of the Second World War Joe was nearly killed in a serious road smash, but he fought his way back to full activity, though one arm was permanently damaged and he limped for the rest of his life because of a leg shortened by compound fractures. He used to make light of this mishap on the rare occasions when he consented to mention it. His physical courage under the impact of this accident was matched by his faith in the outcome of the war all through the black days of 1940 and 1941. Nor should we forget that his courage and his deep family affection were inextricably linked with his religious beliefs, and that these beliefs were free from any trace of self-righteousness. We shall never find a better colleague or a truer friend. Our sympathy goes out to his wife and his daughters.

\title{
MANUEl MÁrQueZ 1872-1961
}

Our readers will regret to learn of the death in Mexico City on June 12,1961, at the age of 89, of Prof. Dr. Manuel Márquez, lately of Madrid, an Honorary Member of the Pan-American Association of Ophthalmology. 